\title{
Preparation of Some Oxa- and Thia-decalins and -propellanes. Barriers to Conformational Interconversion
}

\author{
Inger Reidun Fjeldskaar and Lars Skattebøl \\ Department of Chemistry, university of Oslo, N-0315 Oslo 3, Norway
}

\begin{abstract}
Fjeldskaar, I. R. and Skattebøl, L., 1991. Preparation of Some Oxa- and Thiadecalins and -propellanes. Barriers to Conformational Interconversion. - Acta Chem. Scand. 45: 410-417.

Reactions of 5,6-dihydro-2,3-dimethyl-1,4-dioxin, -1,4-oxathiin and -1,4-dithiin with bromine in the presence of 1,2-ethanediol, 2-mercaptoethanol and 1,2-ethanedithiol, respectively, afforded, in most cases, high yields of the corresponding oxa- and thia-decalins as cis-isomers only. Similar reactions of the bicyclic dihydrodioxins, 2,5-dioxabicyclo[4.4.0] dec-1(6)-ene and the sulfur analogues gave the corresponding propellanes in high yields. The barriers to conformational interconversion were obtained from variable temperature NMR spectra. Other examples of propellanes were obtained; addition of dihalocarbenes to the bicyclic dihydrodioxins furnished the corresponding dihalocyclopropane derivatives, and the photochemical addition of benzophenone gave the expected oxetane.
\end{abstract}

We have recently reported the preparation of dihydro-1,4dioxins and the corresponding sulfur analogues starting from $\alpha$-hydroxy ketones and 1,2-diols, 2-hydroxy thiols and 1,2-dithiols, respectively. ${ }^{1.2}$ In this way both monocyclic and bicyclic derivatives of this class of heterocycle are readily available. We became interested in cycloaddition reactions to these compounds, which contain double bonds vicinally substituted by oxygen and sulfur atoms.

In this paper the preparation of some heterodecalins and propellanes is described, and for some of the derivatives the barrier to conformational interconversion has been determined by recording the variable temperature NMR spectra.

\section{Results and discussion}

Lopez and coworkers have reported that bromination of 5,6-dihydro-2,3-diphenyl-1,4-dioxin with molecular bromine or 2,4,4,6-tetrabromocyclohexadienone in the presence of ethylene glycol afforded cis-1,6-diphenyl-2,5,7,10tetraoxabicyclo[4.4.0]decane. ${ }^{3}$ We wished to extend this reaction using 5,6-dihydro-1,4-dioxin, -1,4-oxathiin, and -1,4-dithiin derivatives as substrates. ${ }^{4}$ These compounds were prepared by an acid-catalysed condensation of the respective $\alpha$-hydroxy ketone with either ethylene glycol, 2-mercaptoethanol or 1,2-ethanedithiol. All reactions went smoothly to the desired products except for that between 3-hydroxy-2-butanone and ethylene glycol. It gave, as the sole product, 2-hydroxy-2,3-dimethyl-1,4-dioxane (1), which resisted dehydration to the dihydrodioxin 2 even after prolonged heating; however, the latter was formed in good overall yield when 1 was treated with zinc chloride in acetic anhydride at room temperature. Bromine was added to a solution of compound 2, ethylene glycol and triethyl-<smiles>CC1OCCOC1(C)O</smiles>

1<smiles>CC(=O)C1(C)OCCS1</smiles>

6<smiles>CC1=C(C)OCCO1</smiles>

2<smiles>CC(=O)C1(C)SCCS1</smiles>

7

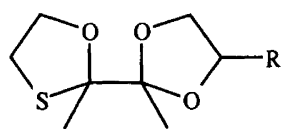

4 a; $\mathrm{R}=\mathrm{H}$

b; $\mathrm{R}=\mathrm{Me}$<smiles>CC1=C(C)SCCO1</smiles><smiles>CC1=C(C)SCCS1</smiles>

11

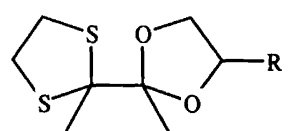

5 a; $\mathrm{R}=\mathrm{H}$

b; $\mathrm{R}=\mathrm{Me}$<smiles>CCC1=C(CC)OCCO1</smiles>

13 a; $n=2$

b; $n=4$ 
amine in carbon tetrachloride and the reaction mixture was left to stir at room temperature until complete, which required from 6 to $10 \mathrm{~h}$. The amine was added as a scavenger for the hydrobromic acid that evolved during the reaction. The product obtained in $84 \%$ yield consisted of cis-1,6dimethyl-2,5,7,10-tetraoxabicyclo[4.4.0]decane (3), which had spectral properties identical with those published. ${ }^{5}$ On the other hand, similar reactions of the dihydrodioxin 2 with 2-mercaptoethanol and 1,2-ethanedithiol gave, in high yields, only the bis-ketals $\mathbf{4 a}$ and $\mathbf{5 a}$, respectively. Structural evidence was obtained from the NMR spectra and selective acid hydrolysis to the corresponding ketones $6^{6}$ and $7 .^{7}$

Similar reactions of 5,6-dihydro-2,3-dimethyl-1,4-oxathiin (8), ${ }^{8}$ prepared from 3-hydroxy-2-butanone and 2-mercaptoethanol, gave mixed results as well. As expected the reaction with bromine and ethylene glycol afforded the bis-ketal $4 a$ as the only product in $88 \%$ yield, and with 1,2-propanediol the corresponding bis-ketal $4 \mathrm{~b}$ was formed as an approximately 1:1 mixture of stereoisomers. Both compounds were hydrolysed to the ketone 6 . However, the reaction of 8 with 2-mercaptoethanol took a different course. A single product was obtained in $85 \%$ yield; the ${ }^{13} \mathrm{C}$ NMR spectrum exhibited two pairs of signals due to the methyl groups and quaternary carbons, respectively, in accordance with the structure cis-1,6-dimethyl-2,10-dioxa5,7-dithiabicyclo[4.4.0]decane (9). Consistent with the cisconfiguration the NMR spectra of 9 were temperature dependent. At room temperature the methylene carbons adjacent to oxygen appear as two broad singlets in the ${ }^{13} \mathrm{C}$ spectrum. The chair-chair interconversion is quite slow compared with that of the tetraoxa analogue 3 , for which the value $44.5 \mathrm{~kJ} \mathrm{~mol}^{-1}$ was obtained. ${ }^{5}$ Coalescence of the signals due to the carbon atoms adjacent to oxygen and sulfur occurred at -5 and $-15^{\circ} \mathrm{C}$, respectively, corresponding to an inversion barrier of $\Delta G^{\neq}=50.2 \mathrm{~kJ} \mathrm{~mol}^{-1}$. Moreover, when compound 8 was subjected to 1,2-ethanedithiol and bromine under the same conditions, cis-1,6dimethyl-2-oxa-5,7,10-trithiabicyclo[4.4.0]decane (10) was the only product obtained in $84 \%$ yield. In this case coalescence of the signals due to the methylene carbons adjacent to oxygen and sulfur occurred at $-30^{\circ} \mathrm{C}$ corresponding to an energy barrier for the inversion process of $\Delta G^{\neq}=$ $47.3 \mathrm{~kJ} \mathrm{~mol}^{-1}$.

Treatment of 5,6-dihydro-2,3-dimethyl-1,4-dithiin (11), ${ }^{9}$ prepared from 3-hydroxy-2-butanone and 1,2-ethanedithiol, with ethylene glycol in the same way gave, in high yield, as the sole product the bis-ketal $\mathbf{5 a}$, and with 1,2 propanediol the bis-ketal $\mathbf{5 b}$ was obtained as a 1:1 mixture of stereoisomers. On the other hand, the reaction of $\mathbf{1 1}$ with 2-mercaptoethanol afforded the decalin 10 in $86 \%$ yield, and by the same procedure ethanedithiol gave rise to cis - 1,6 - dimethyl -2,5,7,10 - tetrathiabicyclo[4.4.0]decane (12) in $88 \%$ yield. The latter exhibited coalescence of the methylene signals in the ${ }^{13} \mathrm{C}$ NMR spectrum at $-15^{\circ} \mathrm{C}$, corresponding to an inversion barrier of $50.3 \mathrm{~kJ} \mathrm{~mol}^{-1}$.

With bicyclic dihydrodioxins and related sulfur ana- logues as substrates several propellane derivatives were prepared under the above reaction conditions; however, the reactions were complete after $30 \mathrm{~min}$ at room temperature. Reactions of the dihydrodioxins $13 \mathbf{a}$ and $13 \mathbf{b}^{2}$ with ethylene glycol gave, as the sole products, the crystalline tetraoxa[4.4.4]propellane $14 \mathrm{a}$ and tetraoxa[6.4.4]propellane 14b, respectively, in $90 \%$ yields. Using either molecular bromine or 2,4,4,6-tetrabromocyclohexadienone the same result was obtained. Both compounds had previously been prepared in low yields by a different approach, ${ }^{10}$ and the reported physical properties are in accordance with our data. The variable temperature NMR spectra of the propellanes $\mathbf{1 4}$ gave some information about their conformational dynamics. At ambient temperature the methylene carbons adjacent to oxygen in 14a gave rise to a broad signal which at $-20^{\circ} \mathrm{C}$ splits into two signals. Coalescence occurs at $-5^{\circ} \mathrm{C}$ corresponding to $\Delta G^{\neq}=50.8 \mathrm{~kJ} \mathrm{~mol}^{-1}$ for this inversion process between the two enantiomeric double chair conformations. The value compares well with that determined for the corresponding hexaoxa[4.4.4]propellane. ${ }^{11}$ In the case of compound $14 \mathrm{~b}$ two different conformational interconversions take place as shown by variable temperature NMR studies. The ring inversion process is similar to that observed for 14a; the lower free energy of activation i.e. $\Delta G^{\neq}=44.4 \mathrm{~kJ} \mathrm{~mol}^{-1}$, calculated from coalescence of the signals due to the methylene carbons adjacent to oxygen at $-39^{\circ} \mathrm{C}$, must be ascribed to the higher flexibility of the eight-membered ring. The other observable process is considerably faster, with $\Delta G^{\neq}=38.6 \mathrm{~kJ}$ $\mathrm{mol}^{-1}$ calculated from coalescence of the quaternary carbons at $-76^{\circ} \mathrm{C}$. The magnitude of this value indicates that pseudorotation is not the process observed but rather an interchange of boat-chair conformations of the eight-membered ring. The transition barrier to this process has been found to be in the order of $40 \mathrm{~kJ} \mathrm{~mol}^{-1},{ }^{12}$ in good agreement with our value.

Propellanes are not always the product from reactions of the dihydrodioxins 13 under these conditions. Reactions of 13a with 2-mercaptoethanol and 1,2-ethanedithiol resulted only in exchange of the heteroatoms with formation of the thermodynamically more stable bicyclic dihydrooxathiin 15 and dihydrodithiin 16, respectively. This exchange is catalysed by $p$-toluenesulfonic acid, ${ }^{1}$ and in a separate experiment we found that the exchange also took place under the influence of a catalytic amount of triethylammonium bromide, an unvoidable component of the above reaction mixture. In order to circumvent this problem additions to compounds 15 and 16 were carried out. Reaction of the former with ethylene glycol gave a mixture of two products in $88 \%$ yield in a ratio of 75:25. They were separated by flash chromatography on silica gel, and identified as the propellanes 17 and 14a, respectively. Evidently the latter is formed by an exchange reaction. The trioxathiapropellane 17 gave rise to variable temperature NMR spectra with a coalescence temperature of $1^{\circ} \mathrm{C}$ for the resonances due to the methylene carbons, corresponding to a transition barrier of $\Delta G^{\neq}=53.6 \mathrm{~kJ} \mathrm{~mol}^{-1}$. Treatment of 15 with 2- 
<smiles>C1CCC2=C(C1)OCCS2</smiles>

15<smiles>CCC1(Br)OCCOC1(CC)CC</smiles>

23 a; $n=2$

b; $n=4$<smiles>C1CCC2=C(C1)SCCS2</smiles>

16<smiles>C1COCCOC2(C1)CCCO2</smiles>

$14 b$<smiles>C1CCC2(OCCS2)C2(C1)OCCO2</smiles>

20<smiles>O=C1CCCCC12SCCS2</smiles>

21

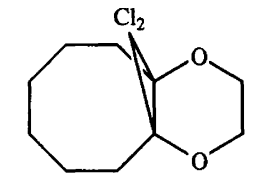

24<smiles></smiles>

25<smiles>C1COC(C2OCCO2)O1</smiles>

27 mercaptoethanol gave, as the sole product, 2,10-dioxa-5,7dithia[4.4.4]propellane (18) in $85 \%$ yield. The positions of the hetero atoms were established from the ${ }^{13} \mathrm{C}$ NMR spectrum which varied with temperature; at $80^{\circ} \mathrm{C}$ fairly sharp signals for the two quaternary carbons were observed at $\delta$ 50.00 and 96.06 , respectively. Coalescence of the signals due to the methylene carbons adjacent to oxygen and sulfur occurred at 35 and $25^{\circ} \mathrm{C}$, respectively, corresponding to an inversion barrier of $57.1 \mathrm{~kJ} \mathrm{~mol}^{-1}$. From the reaction of 15 with 1,2-ethanedithiol, 2-oxa-5,7,10-trithia[4.4.4]propellane (19) was obtained in good yield. In this case coalescence of the NMR signals due to the methylene carbons occurred at $15^{\circ} \mathrm{C}$, corresponding to $\Delta G^{\neq}=56.5 \mathrm{~kJ} \mathrm{~mol}^{-1}$ for the interconversion barrier.

Reaction of the dihydrodithiin 16 with ethylene glycol under the above conditions proceeded rapidly to one product, which was identified as the bis-ketal 20 based on spectral evidence and hydrolysis to the known ketone $21 .{ }^{13}$ On the other hand, the reaction with 2-mercaptoethanol afforded as only product the propellane 19 in $79 \%$ yield. Reaction with 1,2-ethanedithiol gave in $78 \%$ yield 2,5,7,10-tetrathia[4.4.4]propellane (22), which exhibited variable temperature $\mathrm{NMR}$ spectra; in the ${ }^{13} \mathrm{C}$ spectrum coalescence of the methylene signals adjacent to sulfur was observed at $14^{\circ} \mathrm{C}$ corresponding to $\Delta G^{\neq}=55.2 \mathrm{~kJ} \mathrm{~mol}^{-1}$.

The epoxides from the bicyclic dihydrodioxins and the sulfur analogues would be examples of [n.4.1]propellane derivatives; however, oxidation of the dihydrodioxins $\mathbf{1 3}$ with hydrogen peroxide had previously been shown to yield not oxiranes but lactones by ring opening, and the sulfur analogues are oxidized preferentially at sulfur. ${ }^{1}$ The addition of dihalocarbenes to the double bond of dihydrodioxins has been reported, ${ }^{14}$ and similar additions to the bicyclic dihydrodioxins afforded examples of dioxa[n.4.1]propellanes. Thus, the reaction of compound 13a with dibromocarbene, generated from bromoform and sodium hydroxide under phase-transfer conditions, gave the [4.4.1]propellane $23 \mathrm{a}$ in $82 \%$ yield. A similar reaction of the homologue $13 \mathrm{~b}$ afforded $24 \mathrm{~b}$ as the sole product, and the reaction of 13b with dichlorocarbene proceeded equally well to give the corresponding propellane $\mathbf{2 4}$ in high yield.

Cycloaddition of ketenes to the double bond of the bicyclic dihydrodioxins should furnish examples of [n.4.2]propellanes. To our surprise, however, treatment of $\mathbf{1 3 b}$ with dichloroketene resulted only in recovery of starting material whether the ketene was generated from dichloroacetyl chloride and triethylamine ${ }^{15}$ or from trichloroacetyl chloride and zinc. ${ }^{16}$ The use of phosphorus oxychloride as solvent had no apparent effect. ${ }^{17}$ This contrasts with the result from the reaction of 2,3-dihydro-1,4-dioxin itself with diphenylketene ${ }^{18}$ and the reaction of 2,3-dihydropyran and dichloroketene ${ }^{15}$ which both gave the expected adducts in moderate yields. After this work was completed Fetizon and Hanna ${ }^{19}$ reported a poor yield of the adduct from 2,3-dihydro-1,4-dioxin and dichloroketene, generated ultrasonically from trichloroacetyl chloride and zinc. If one assumes the ketene to behave as an electrophilic reagent, the reaction will initially generate on the substrate a positive charge that, in the case of the dihydrodioxins, will be localised on the carbon atom adjacent to oxygen. The stabilising effect of the latter should actually promote the reaction; the observed lack of reactivity must therefore be a result of the lower nucleophilicity of the dihydrodioxin double bond compared with that of vinyl ethers, as well as the presence of detrimental steric effects. Further indications of reduced nucleophilicity may be found in the work of Huisgen and Steiner ${ }^{20}$ who observed a lower rate of addition of tetracyanoethylene to 1,2-diethoxyethylene than to 1-butenyl ethyl ether, and in the reduced proton acidity of 2,3-dihydro-1,4-dioxin compared with that of 2,3-dihydropyran. ${ }^{21}$ An example of an [n.4.2]propellane was finally obtained by photochemical cycloaddition of a ketone to the double bond. Irradiation of a solution of the dihydrodioxin 13b and benzophenone in benzene with a medium pressure $250 \mathrm{~W}$ UV lamp resulted in a slow reaction which was not complete even after $80 \mathrm{~h}$ at room temperature. One product was formed which was separated from unchanged starting material by flash chroma- 

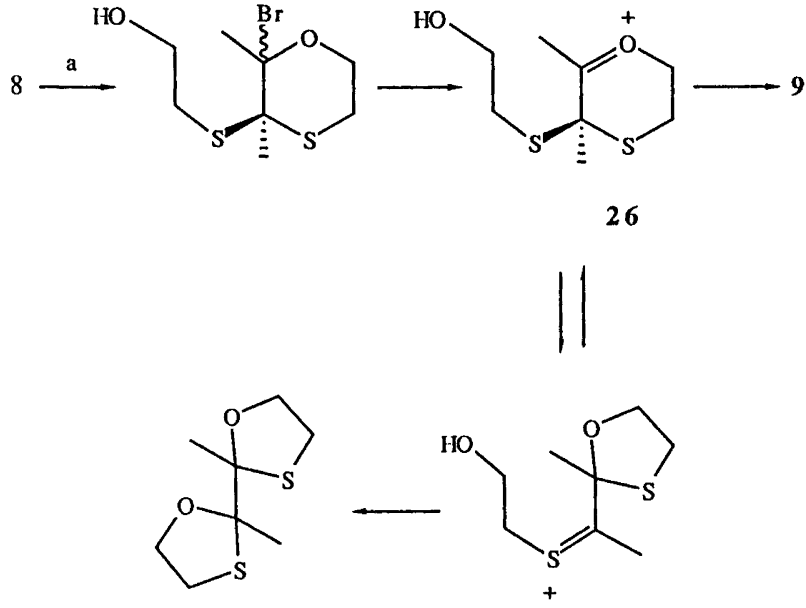

a) $\mathrm{Br}_{2}, \mathrm{HSCH}_{2} \mathrm{CH}_{2} \mathrm{OH}, \mathrm{Et}_{3} \mathrm{~N}, \mathrm{CCl}_{4}$

\section{Scheme 1.}

tography and identified as the diphenyltrioxa[6.4.2]propellane 25. Several photochemically induced cycloadditions to 5,6-dihydro-1,4-dioxin have been reported. ${ }^{22}$

The conversion of the dihydrodioxin 8 into the decalin 9 , as depicted in Scheme 1, examplifies the general reaction described in this paper. It is assumed that the bromines are displaced with formation of the intermediate cation 26 . Hence, formation of either cis- or trans-decalin will depend on from which face of the cation ring closure takes place. Alternatively, consecutive rearrangement of 26 and ring closure provide an explanation for the formation of the bis-ketals. It is interesting to note that in all our reactions one of the reaction paths appears exclusive; a mixture of the fused ring compound and the isomeric bis-ketal was never encountered, and acid-catalysed interconversion did not take place. Jørgensen et al. ${ }^{23}$ have predicted by calculations that cis-2,5,7,10-tetraoxadecalin is $12-15 \mathrm{~kJ} \mathrm{~mol}^{-1}$ more stable than the trans-isomer and $16-20 \mathrm{~kJ} \mathrm{~mol}^{-1}$ more stable than the isomeric bis-acetal 27; the anomeric effect of oxygen is essential in explaining this difference in stability. ${ }^{24}$ This stereoelectronic effect is important for sulfurcontaining derivatives as well, giving rise to a pronounced preference for the axial form in both monothio and dithio acetals, ${ }^{25}$ and simple MM2 calculations indicate the same order of stability for the sulfur-containing isomers; the cis-decalin derivative is more stable than either the transisomer or the isomeric bis-thioketal. Athough the decalins from the above reactions are invariably formed in the thermodynamically preferred cis-configuration, the formation of the bis-ketals 4, 5 and 20 suggests that the products are kinetically controlled. The reported preferential formation, from another kind of reaction, of trans-2,5,7,10-tetrathiabicyclo[4.4.0]decane, which could not be isomerised to the cis-isomer, is interesting in this connection. ${ }^{26}$
Table 1. The free energy of activation, $\Delta G^{*} \mathrm{~kJ} \mathrm{~mol}^{-1}$, for the interconversion of decalins and propellanes.

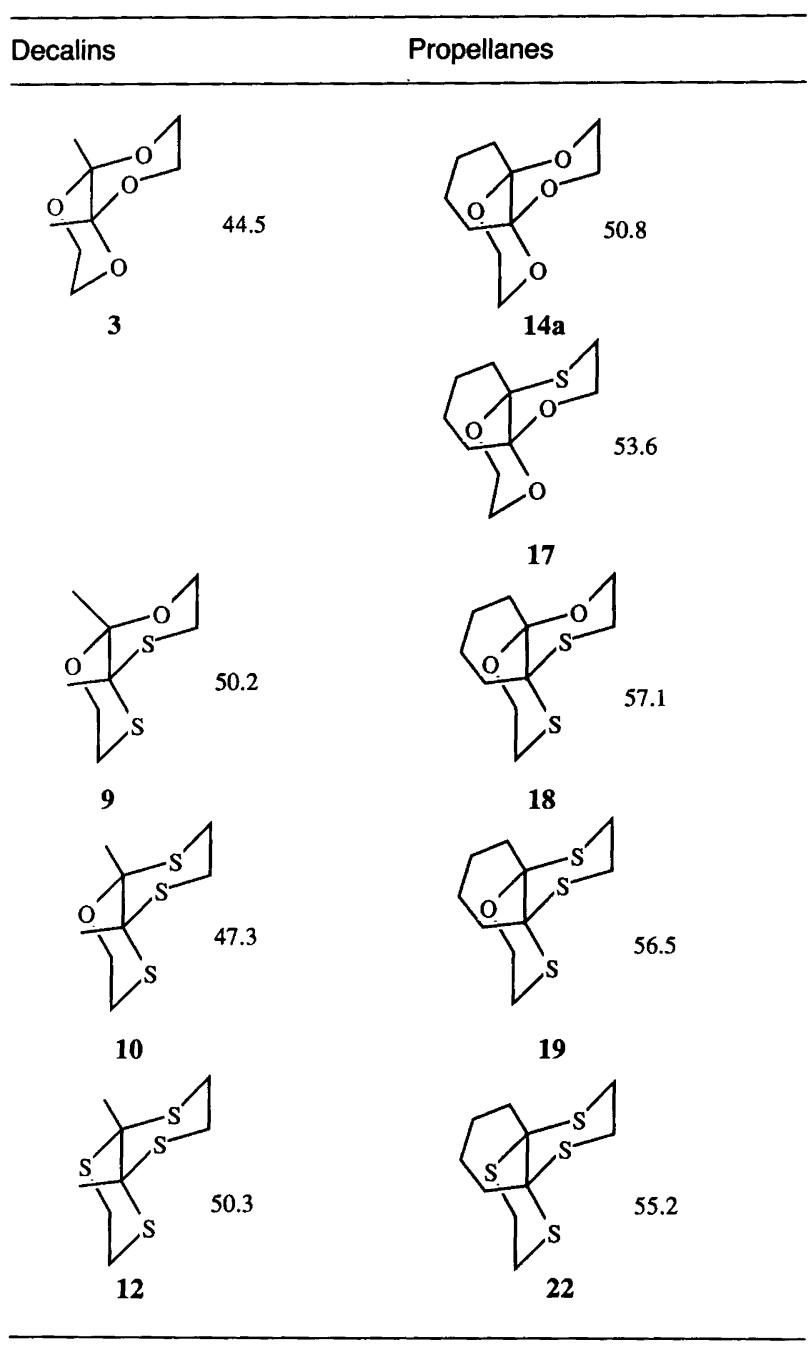

Regarding the conformational interconversion of the products, the [4.4.4]propellanes generally have a higher free energy of activation for this process than those observed for the corresponding cis-dimethyldecalins as shown by the results compiled in Table 1 . The increase must be attributed to the larger angular strain caused by the additional six-membered ring in the former group of compounds. The negligible difference in the barriers to inversion for the propellane $\mathbf{1 4 b}$, with a bridged eight-membered ring, and the dimethyldecalin 3 favours this assumption. On the other hand the effect on the inversion barrier caused by replacement of oxygen with sulfur is difficult to ascertain. The anomeric effect for sulfur appears to be smaller than for oxygen, and it seems reasonable to expect the inversion barrier to decrease with the number of sulfur atoms; moreover, the extended carbon-sulfur bond length should lead to a smaller contribution from van der Waals' interactions, resulting in a reduced barrier to inversion as well. Comparing the $\Delta G^{\neq}$values recorded in 
Table 1 for both the cis-dimethyldecalins and the [4.4.4]propellanes, replacement of one oxygen with sulfur generally results in a higher barrier to conformational inversion. However, further substitution with sulfur does not necessarily cause a further decreased rate of inversion; the decalins 9 and 12, containing two and four sulfur atoms, respectively, have similar barriers to inversion and the propellanes 18 and 19, which differ structurally by one sulfur atom, invert at about the same rate. It seems that more data are needed before the conformational dynamics of cyclic sulfur-containing compounds can be rationalized.

\section{Experimental}

General. GLC analyses were performed on a $30 \mathrm{~m}$ wallcoated capillary column of SP2100. IR spectra were recorded on a Perkin Elmer 1310 instrument. MS spectra were obtained on a Micromass $7070 \mathrm{~F}$ instrument coupled to a Carlo Erba 4200 chromatograph. NMR spectra were recorded on Varian XL-300 and 200 instruments. The variable temperature NMR spectra were recorded on spinning samples dissolved in either $\mathrm{CD}_{2} \mathrm{Cl}_{2}$ (below $-50^{\circ} \mathrm{C}$ ) or $\mathrm{CDCl}_{3}$. The temperatures were calibrated against methanol. Free energies of activation were estimated by absolute rate theory from the rate constants obtained at the coalescence temperatures using the relation $\Delta G^{\neq}=R T_{\mathrm{c}}[22.96$ $\left.+\log \left(T_{\mathfrak{\imath}} / \delta v\right)\right] \cdot{ }^{27}$

5,6-Dihydro-2,3-dimethyl-1,4-dioxin (2). A solution of 3hydroxy-2-butanone $(1.5 \mathrm{~g}, 17.0 \mathrm{mmol})$, ethylene glycol $(1.37 \mathrm{~g}, 22.1 \mathrm{mmol})$ and catalytic amounts of $p$-toluenesulfonic acid in benzene $(50 \mathrm{ml})$ was heated under reflux for $5 \mathrm{~h}$. Flash chromatography of the crude product gave 2 hydroxy-2,3-dimethyl-1,4-dioxane $(1 ; 1.92 \mathrm{~g}, 86 \%)$ as a $3: 1$ mixture of stereoisomers. As it was not possible to separate them, the spectral data were obtained from the mixture. IR (film): $3600-3500,1375,1140-1040 \mathrm{~cm}^{-1}$. GC/MS (CI): $\mathrm{m} / z$ $115\left(M^{+}+1-\mathrm{H}_{2} \mathrm{O}\right)$. Major isomer: 'H NMR (300 MHz, $\left.\mathrm{CDCl}_{3}\right): \delta 1.13(\mathrm{~d}, 3 \mathrm{H}), 1.34(\mathrm{~s}, 3 \mathrm{H}), 3.59(\mathrm{q}, 1 \mathrm{H}), 3.96$ $(\mathrm{m}, 4 \mathrm{H}) .{ }^{13} \mathrm{C}$ NMR $\left(75 \mathrm{MHz}, \mathrm{CDCl}_{3}\right): \delta 15.75,19.44$ $\left(\mathrm{CH}_{3}\right), 64.58,64.84\left(\mathrm{CH}_{2}-\mathrm{O}\right), 77.13(\mathrm{CH}), 110.74(\mathrm{CH})$. Minor isomer: 'H NMR (300 MHz, $\left.\mathrm{CDCl}_{3}\right): \delta 1.17(\mathrm{~d}, 3$ $\mathrm{H}), 1.29(\mathrm{~s}, 3 \mathrm{H}), 3.59(\mathrm{q}, 1 \mathrm{H}), 3.96(\mathrm{~m}, 4 \mathrm{H}) .{ }^{13} \mathrm{C}$ NMR $\left(75 \mathrm{MHz}, \mathrm{CDCl}_{3}\right): \delta 15.91,19.70\left(\mathrm{CH}_{3}\right), 64.72,64.89$ $\left(\mathrm{CH}_{2}-\mathrm{O}\right), 78.66(\mathrm{CH}), 111.00(\mathrm{C})$. A solution of the hydroxydioxane $1(1.0 \mathrm{~g}, 7.5 \mathrm{mmol})$ and catalytic amounts of $\mathrm{ZnCl}_{2}$ in acetic anhydride $(5 \mathrm{ml})$ was stirred for $2 \mathrm{~h}$ at room temperature. Flash chromatography of the crude product gave $2(0.82 \mathrm{~g}, 96 \%)$ as a liquid. The spectral data were in accordance with those in the literature. ${ }^{4}$

General procedure. cis-1,6-dimethyl-2,5,7,10-tetraoxabicyclo[4.4.0]decane $(3)$. Bromine $(0.70 \mathrm{~g}, 4.39 \mathrm{mmol})$ was added dropwise with stirring to an ice-cooled solution of the dihydrodioxin $2(0.50 \mathrm{~g}, 4.39 \mathrm{mmol})$, ethylene glycol (2 $\mathrm{ml})$ and triethylamine $(0.90 \mathrm{~g}, 8.82 \mathrm{mmol})$ in $\mathrm{CCl}_{4}(15 \mathrm{ml})$. After $10 \mathrm{~h}$ at room temperature water was added, and the product extracted with ether. The organic layer was washed with water and dried $\left(\mathrm{MgSO}_{4}\right)$. Evaporation of solvents followed by flash chromatography of the residue gave compound $3(0.64$ g, $84 \%)$, m.p. $90-91^{\circ} \mathrm{C}$, from light petroleum (lit. ${ }^{5}$ m.p. $91{ }^{\circ} \mathrm{C}$ ). The ${ }^{1} \mathrm{H}$ NMR spectrum, which varied with temperature, was in accordance with that in the literature. ${ }^{5}$

1,1'-Dimethyl-2,5-dioxa-2',5'-oxathiabicyclopentane (4a). The compound was obtained from 2 and ethylene glycol according to the general procedure in $86 \%$ yield, m.p. $72-73^{\circ} \mathrm{C}$, from hexane, ${ }^{1} \mathrm{H}$ NMR $\left(300 \mathrm{MHz}, \mathrm{CDCl}_{3}\right): \delta 1.36$ $(\mathrm{s}, 3 \mathrm{H}), 1.56(\mathrm{~s}, 3 \mathrm{H}), 2.97(\mathrm{~m}, 2 \mathrm{H}), 4.01(\mathrm{~m}, 6 \mathrm{H}) \cdot{ }^{13} \mathrm{C}$ NMR $\left(75 \mathrm{MHz}, \mathrm{CDCl}_{3}\right): \delta 21.25,25.61\left(\mathrm{CH}_{3}\right), 34.09$ $\left(\mathrm{CH}_{2}-\mathrm{S}\right), 66.06,66.16,72.43\left(\mathrm{CH}_{2}-\mathrm{O}\right), 98.97(\mathrm{O}-\mathrm{C}-\mathrm{S})$, 112.54 (O-C-O). IR (film): 1440, 1370, 1210, 1180, 1040 $\mathrm{cm}^{-1}$. GC/MS (CI): $\mathrm{m} / z 191\left(32, M^{+}+1\right), 131$ (100). The same compound was obtained in $88 \%$ yield from a similar reaction of the dihydrooxathiin 8 and ethylene glycol.

1,1',3-Trimethyl-2,5-dioxa-2,5'-oxathiabicyclopentane (4b). The compound was prepared from 8 and 1,2-propanediol in $87 \%$ yield as a 1:1 mixture of stereoisomers. As we were unable to separate the isomers, we obtained the spectral data from the mixture.

Isomer I: 'H NMR (300 MHz, $\left.\mathrm{CDCl}_{3}\right): \delta 1.12(\mathrm{~d}, 3 \mathrm{H})$, $1.52(\mathrm{~d}, 3 \mathrm{H}), 1.55(\mathrm{~s}, 3 \mathrm{H}), 2.06(\mathrm{~m}, 1 \mathrm{H}), 3.30(\mathrm{~m}, 2 \mathrm{H})$, $3.84(\mathrm{~m}, 1 \mathrm{H}), 4.14(\mathrm{~m}, 2 \mathrm{H}), 4.22(\mathrm{~m}, 1 \mathrm{H}) .{ }^{13} \mathrm{C}$ NMR $(75$ $\left.\mathrm{MHz}, \mathrm{CDCl}_{3}\right): \delta 17.09,20.69,21.47\left(\mathrm{CH}_{3}\right), 24.68\left(\mathrm{CH}_{2}-\mathrm{S}\right)$, 64.52, $66.26\left(\mathrm{CH}_{2}-\mathrm{O}\right), 66.63(\mathrm{CH}-\mathrm{O}), 79.29$ (O-C-S), 96.21 (O-C-O).

Isomer II: ${ }^{1} \mathrm{H}$ NMR (300 MHz, $\mathrm{CDCl}_{3}$ ): $\delta 1.04(\mathrm{~d}, 3 \mathrm{H})$, $1.42(\mathrm{~s}, 3 \mathrm{H}), 1.68(\mathrm{~s}, 3 \mathrm{H}), 2.53(\mathrm{~m}, 1 \mathrm{H}), 3.08(\mathrm{~m}, 1 \mathrm{H})$, $3.63(\mathrm{~m}, 2 \mathrm{H}), 3.84(\mathrm{~m}, 1 \mathrm{H}), 4.15(\mathrm{~m}, 1 \mathrm{H}), 4.42(\mathrm{~m}, 1 \mathrm{H})$. ${ }^{13} \mathrm{C}$ NMR $\left(75 \mathrm{MHz}, \mathrm{CDCl}_{3}\right): \delta 16.42,20.33,26.19\left(\mathrm{CH}_{3}\right)$, $28.12\left(\mathrm{CH}_{2}-\mathrm{S}\right), 59.86,63.37\left(\mathrm{CH}_{2}-\mathrm{O}\right), 69.50(\mathrm{CH}-\mathrm{O})$, 81.11 (O-C-S), $96.20(\mathrm{O}-\mathrm{C}-\mathrm{O})$.

1,1'-Dimethyl-2,5-dioxa-2',5'-dithiabicyclopentane (5a). The compound was obtained from 2 and 1,2-ethanedithiol as a liquid in $85 \%$ yield. ${ }^{1} \mathrm{H}$ NMR $\left(300 \mathrm{MHz}, \mathrm{CDCl}_{3}\right): \delta$ $1.48(\mathrm{~s}, 3 \mathrm{H}), 1.76(\mathrm{~s}, 3 \mathrm{H}), 3.26(\mathrm{~m}, 4 \mathrm{H}), 3.95(\mathrm{~m}, 2 \mathrm{H})$, $4.08(\mathrm{~m}, 2 \mathrm{H}) .{ }^{13} \mathrm{C}$ NMR (75 MHz, $\left.\mathrm{CDCl}_{3}\right): \delta 21.94,28.69$ $\left(\mathrm{CH}_{3}\right), 40.75\left(\mathrm{CH}_{2}-\mathrm{S}\right), 66.42\left(\mathrm{CH}_{2}-\mathrm{O}\right), 73.66$ (S-C-S), 114.25 (O-C-O). IR (film): 1450, 1210, 1175, $1070 \mathrm{~cm}^{-1}$. GC/MS (CI): $m / z 207\left(100, M^{+}+1\right)$. The same compound was obtained in $88 \%$ yield from a similar reaction of the dihydrodithiin 11 and ethylene glycol.

1,1',3-Trimethyl-2,5-dioxa-2',5'-dithiabicyclopentane (5b). The compound was obtained from 11 and 1,2-propanediol as an approximately 1:1 mixture of stereoisomers in $85 \%$ yield. As it was not possible to separate the isomers, the spectral data were obtained from the mixture.

Isomer I: 'H NMR (300 MHz, $\left.\mathrm{CDCl}_{3}\right): \delta 1.25(\mathrm{~d}, 3 \mathrm{H})$, $1.54(\mathrm{~s}, 3 \mathrm{H}), 1.78(\mathrm{~s}, 3 \mathrm{H}), 3.29(\mathrm{~m}, 4 \mathrm{H}), 3.47(\mathrm{q}, 1 \mathrm{H})$, $4.21(\mathrm{q}, 1 \mathrm{H}), 4.46(\mathrm{~m}, 1 \mathrm{H}) .{ }^{13} \mathrm{C}$ NMR $\left(75 \mathrm{MHz}, \mathrm{CDCl}_{3}\right): \delta$ 
19.09, 23.21, 28.20, $\left(\mathrm{CH}_{3}\right), 40.27\left(\mathrm{CH}_{2}-\mathrm{S}\right), 72.19,74.46$ $\left(\mathrm{CH}_{2}-\mathrm{O}\right), 74.00(\mathrm{~S}-\mathrm{C}-\mathrm{S}), 114.51(\mathrm{O}-\mathrm{C}-\mathrm{O})$.

Isomer II: ${ }^{1} \mathrm{H}$ NMR $\left(300 \mathrm{MHz}, \mathrm{CDCl}_{3}\right): \delta 1.32(\mathrm{~d}, 3 \mathrm{H})$, $1.51(\mathrm{~s}, 3 \mathrm{H}), 1.78(\mathrm{~s}, 3 \mathrm{H}), 3.29(\mathrm{~m}, 4 \mathrm{H}), 3.62(\mathrm{q}, 1 \mathrm{H})$, $4.03(\mathrm{q}, \mathrm{H}), 4.28(\mathrm{~m}, 1 \mathrm{H}) .{ }^{13} \mathrm{C}$ NMR $\left(75 \mathrm{MHz}, \mathrm{CDCl}_{3}\right): \delta$ 16.78, 21.86, $28.20\left(\mathrm{CH}_{3}\right), 40.21\left(\mathrm{CH}_{2}-\mathrm{S}\right), 72.61,72.77$ $\left(\mathrm{CH}_{2}-\mathrm{O}\right), 73.51$ (S-C-S), 114.31 (O-C-O). IR (film): $1440,1355,1200,1165,1080 \mathrm{~cm}^{-1}$.

2-Acetyl-2-methyl-1,3-oxathiolane (6). Hydrolysis of either 4a or $4 \mathbf{b}(2.3 \mathrm{mmol})$ in acetone $(20 \mathrm{ml})$, water $(4 \mathrm{ml})$ and catalytic amounts of $p$-toluenesulfonic acid gave the ketone 6 in $93 \%$ yield, with spectral properties identical with those in the literature. ${ }^{6}$

2-Acetyl-2-methyl-1,3-dithiolane (7). Acid-catalysed hydrolysis of either $5 \mathbf{a}$ or $5 \mathbf{b}$ as described for 6 gave the ketone 7 in $92 \%$ yield with spectral properties identical with those in the literature. ${ }^{7}$

5,6-Dihydro-2,3-dimethyl-1,4-oxathiin (8) was prepared in $91 \%$ yield from 3-hydroxy-2-butanone and 2-mercaptoethanol by the previously described procedure. ${ }^{1}$ The spectral data were identical with those published. ${ }^{8}$

cis-1,6-Dimethyl-2,10-dioxa-5,7-dithiabicyclo[4.4.0]decane (9). The compound was obtained from 8 and 2-mercaptoethanol in $85 \%$ yield. The NMR spectra varied with temperature, and the following NMR spectra were recorded at $49^{\circ} \mathrm{C} .{ }^{1} \mathrm{H}$ NMR $\left(300 \mathrm{MHz}, \mathrm{CDCl}_{3}\right): \delta 1.59(\mathrm{~s}, 3$ H), $1.71(\mathrm{~s}, 3 \mathrm{H}), 2.78(\mathrm{~d}, 4 \mathrm{H}), 3.89(\mathrm{~m}, 2 \mathrm{H}), 4.32(\mathrm{~m}, 2$ H). ${ }^{13} \mathrm{C}$ NMR $\left(75 \mathrm{MHz}, \mathrm{CDCl}_{3}\right): \delta 20.57,25.65\left(\mathrm{CH}_{3}\right)$, $26.53\left(\mathrm{CH}_{2}-\mathrm{S}\right), 47.92(\mathrm{~S}-\mathrm{C}-\mathrm{S}), 62.39-63.89\left(\mathrm{CH}_{2}-\mathrm{O}\right)$, 97.34 (O-C-O). IR (film): 1450, 1365, 1210, 1175, 1070 $\mathrm{cm}^{-1}$. GC/MS (CI): $\mathrm{m} / z 207\left(48, M^{+}+1\right), 147$ (100).

cis-1,6-Dimethyl-2-oxa-5,7,10-trithiabicyclo[4.4.0]decane (10). The compound was obtained from 8 and 1,2-ethanedithiol in $84 \%$ yield. Variable temperature NMR spectra were recorded. ${ }^{1} \mathrm{H}$ NMR $\left(300 \mathrm{MHz}, \mathrm{CDCl}_{3}\right): \delta 1.77$ (s, 3 $\mathrm{H}), 1.87(\mathrm{~s}, 3 \mathrm{H}), 2.99(\mathrm{~m}, 1 \mathrm{H}), 3.08(\mathrm{~m}, 1 \mathrm{H}), 3.29(\mathrm{~m}, 4$ $\mathrm{H}), 4.11(\mathrm{~m}, 1 \mathrm{H}), 4.43(\mathrm{~m}, 1 \mathrm{H}) .{ }^{13} \mathrm{C}$ NMR $(75 \mathrm{MHz}$, $\left.\mathrm{CDCl}_{3}\right)$ : $\delta 27.50,30.75\left(\mathrm{CH}_{3}\right), 35.21,40.97,41.14\left(\mathrm{CH}_{2}-\mathrm{S}\right)$, $72.55\left(\mathrm{CH}_{2}-\mathrm{O}\right), 77.28$ (S-C-S), 102.89 (O-C-S). IR (film): $1435,1365,1270,1220,1130,1060,1015 \mathrm{~cm}^{-1}$. GC/MS (CI): $m / z 223\left(24, M^{+}+1\right), 163(100)$.

The same compound was obtained in $86 \%$ yield as the sole product from the reaction of the dihydrodithiin $\mathbf{1 1}$ and 2-mercaptoethanol.

5,6-Dihydro-2,3-dimethyl-1,4-dithiin (11) was prepared in $92 \%$ yield from 3-hydroxy-2-butanone and 1,2-ethanedithiol by the previously described method. ${ }^{1}$ The spectral data were identical with those published. ${ }^{9}$

cis-1,6-Dimethyl-2,5,7,10-tetrathiabicyclo[4.4.0]decane (12). The compound was obtained from 11 and 1,2-ethanedithiol in $88 \%$ yield as crystals, m.p. $73-74^{\circ} \mathrm{C}$, from methylene chloride. The compound exhibited temperature-variable NMR spectra. ${ }^{1} \mathrm{H}$ NMR $\left(300 \mathrm{MHz}, \mathrm{CDCl}_{3}\right): \delta 2.06(\mathrm{~s}, 6 \mathrm{H})$, $3.37(\mathrm{~m}, 4 \mathrm{H}), 3.46(\mathrm{~m}, 4 \mathrm{H}) .{ }^{13} \mathrm{C} \mathrm{NMR}\left(75 \mathrm{MHz}, \mathrm{CDCl}_{3}\right)$ :

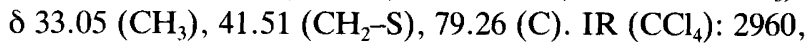
$2900,1680,1440,1320,1100 \mathrm{~cm}^{-1}$.

2,5,7,10-Tetraoxa[4.4.4]propellane (14a). The compound was obtained from 2,5-dioxabicyclo[4.4.0]dec-1(6)-ene $(13 a)^{2}$ and ethylene glycol as crystals in $90 \%$ yield, m.p. $101^{\circ} \mathrm{C}$ (lit. ${ }^{10}$ m.p. $102^{\circ} \mathrm{C}$ ). The compound exhibited temperature-variable NMR spectra. ${ }^{1} \mathrm{H}$ NMR $(300 \mathrm{MHz}$, $\mathrm{CDCl}_{3}$ ): $\delta 1.55(\mathrm{~s}, 4 \mathrm{H}), 1.81(\mathrm{br} \mathrm{s}, 4 \mathrm{H}), 3.72($ br s, $4 \mathrm{H})$, 4.03 (br s, $4 \mathrm{H}$ ). ${ }^{13} \mathrm{C} \mathrm{NMR}\left(75 \mathrm{MHz}, \mathrm{CDCl}_{3}\right): \delta 22.18,31.16$ $\left(\mathrm{CH}_{2}\right), 60.76\left(\mathrm{CH}_{2}-\mathrm{O}\right), 94.34(\mathrm{C})$.

Replacing bromine with 2,4,4,6-tetrabromo-2,5-cyclohexadienone in the above procedure gave 14a in $92 \%$ yield.

9,12,13,16-Tetraoxa[6.4.4]propellane (14b). The compound was obtained from 9,12-dioxabicyclo[6.4.0]dodec-1(8)-ene $(\mathbf{1 3 b})^{2}$ and ethylene glycol in $90 \%$ yield as crystals, m.p. $80^{\circ} \mathrm{C}$ (lit. ${ }^{10}$ m.p. $80-81^{\circ} \mathrm{C}$ ). The compound exhibited temperature-variable NMR spectra. ${ }^{1} \mathrm{H}$ NMR $(300 \mathrm{MHz}$, $\left.\mathrm{CDCl}_{3}\right): \delta 1.59(\mathrm{~s}, 4 \mathrm{H}), 1.72(\mathrm{~s}, 4 \mathrm{H}), 2.12(\mathrm{~m}, 4 \mathrm{H}), 3.74$ $(\mathrm{m}, 4 \mathrm{H}), 4.40(\mathrm{~m}, 4 \mathrm{H}) .{ }^{13} \mathrm{C}$ NMR $\left(75 \mathrm{MHz}, \mathrm{CDCl}_{3}\right): \delta$ 20.97, 27.37, $32.83\left(\mathrm{CH}_{2}\right), 60.76\left(\mathrm{CH}_{2}-\mathrm{O}\right), 96.05(\mathrm{C})$. IR (KBr): 1438, 1465, 1280, 1260, 1190, $1090 \mathrm{~cm}^{-1}$. GC/MS: $m / z 229\left(100 ; M^{+}+1\right)$.

2,5,7-Trioxa-10-thia[4.4.4]propellane (17). Reaction of 2oxa-5-thiabicyclo[4.4.0]dec-1(6)-ene $(15)^{2}$ and ethylene glycol gave two products in a $75: 25$ ratio. Flash chromatography afforded 14a $(0.24 \mathrm{~g}, 22 \%)$, and $17(0.68 \mathrm{~g}, 62 \%)$, m.p. $95-96^{\circ} \mathrm{C}$, from hexane. ${ }^{1} \mathrm{H}$ NMR $\left(300 \mathrm{MHz}, \mathrm{CDCl}_{3}\right)$ : ठ 1.51-1.69 (m, $4 \mathrm{H}), 2.25-2.75(\mathrm{~m}, 2 \mathrm{H}), 3.72-4.32(\mathrm{~m}, 6$ H). ${ }^{13} \mathrm{C} \mathrm{NMR}\left(75 \mathrm{MHz}, \mathrm{CDCl}_{3}\right): \delta 22.34,22.59,26.21$, $31.58\left(\mathrm{CH}_{2}\right), 34.91\left(\mathrm{CH}_{2}-\mathrm{S}\right), 60.47,60.75,62.84\left(\mathrm{CH}_{2}-\mathrm{O}\right)$, $80.96(\mathrm{O}-\mathrm{C}-\mathrm{S}), 95.47$ (O-C-O). IR $\left(\mathrm{CCl}_{4}\right): 1440,1430$, $1295,1175,1090 \mathrm{~cm}^{-1}$.

2,10-Dioxa-5,7-dithial4.4.4]propellane (18). The compound was obtained from 15 and 2-mercaptoethanol in $85 \%$ yield as colourless crystals, m.p. $113-114^{\circ} \mathrm{C}$, from hexane. The compound exhibited temperature-variable NMR spectra. ${ }^{1} \mathrm{H}$ NMR $\left(300 \mathrm{MHz}, \mathrm{CDCl}_{3}\right)$ at $80^{\circ} \mathrm{C}: \delta$ 1.60-1.75 (br s, $4 \mathrm{H}$ ), 2.10-2.35 (br s, $4 \mathrm{H}$ ), 2.65-3.10 (br s, $4 \mathrm{H}), 3.95(\mathrm{~m}, 2 \mathrm{H}), 4.34(\mathrm{~m}, 2 \mathrm{H}) .{ }^{13} \mathrm{C}$ NMR $(75 \mathrm{MHz}$, $\left.\mathrm{CDCl}_{3}\right)$ at $80^{\circ} \mathrm{C}: \delta 22.55,23.02\left(\mathrm{CH}_{2}\right), 26.49\left(\mathrm{CH}_{2}-\mathrm{S}\right)$, 31.15, $37.96\left(\mathrm{CH}_{2}\right), 50.00(\mathrm{~S}-\mathrm{C}-\mathrm{S}), 62.86\left(\mathrm{CH}_{2}-\mathrm{O}\right), 96.06$ (O-C-O). IR $\left(\mathrm{CCl}_{4}\right): 1455,1210,1175,1070 \mathrm{~cm}^{-1}$.

2-Oxa-5,7,10-trithial4.4.4]propellane (19). The compound was obtained from 15 and 1,2-ethanedithiol in $81 \%$ yield as crystals, m.p. $100^{\circ} \mathrm{C}$, from hexane. The compound exhibited temperature-variable NMR spectra. ${ }^{1} \mathrm{H}$ NMR (300 $\left.\mathrm{MHz}, \mathrm{CDCl}_{3}\right): \delta 1.61(\mathrm{~m}, 4 \mathrm{H}), 2.07(\mathrm{~m}, 1 \mathrm{H}), 2.21(\mathrm{~m}, 2$ 
H), $2.32(\mathrm{~m}, 1 \mathrm{H}), 2.98(\mathrm{~m}, 1 \mathrm{H}), 3.23(\mathrm{~m}, 1 \mathrm{H}), 3.45(\mathrm{~m}, 2$ $\mathrm{H}), 4.08(\mathrm{~m}, 1 \mathrm{H}), 4.58(\mathrm{~m}, 1 \mathrm{H}) .{ }^{13} \mathrm{C}$ NMR $(75 \mathrm{MHz}$, $\left.\mathrm{CDCl}_{3}\right): \delta 24.92,25.10,34.49\left(\mathrm{CH}_{2}\right), 36.68,39.94,45.20$ $\left(\mathrm{CH}_{2}-\mathrm{S}\right), 72.36\left(\mathrm{CH}_{2}-\mathrm{O}\right), 77.23(\mathrm{~S}-\mathrm{C}-\mathrm{S}), 103.58(\mathrm{~S}-\mathrm{C}-\mathrm{O})$. IR (film): 1438, 1270, 1220, 1130, 1060, $1015 \mathrm{~cm}^{-1}$.

1,3-Dioxolane-2-spiro-1'-cyclohexane-3'-spiro-2"-(1", 3"-dithiolane) (20). The compound was obtained from 2,5-dithiabicyclo[4.4.0] dec-1(6)-ene (16) ${ }^{2}$ and ethylene glycol in $78 \%$ as crystals, m.p. $56{ }^{\circ} \mathrm{C}$, from hexane. 'H NMR $(300$ $\left.\mathrm{MHz}, \mathrm{CDCl}_{3}\right): \delta 1.57(\mathrm{~m}, 4 \mathrm{H}), 1.84(\mathrm{~m}, 2 \mathrm{H}), 2.21(\mathrm{~m}, 2$ H), $3.21(\mathrm{~m}, 2 \mathrm{H}), 3.27(\mathrm{~m}, 2 \mathrm{H}), 4.00(\mathrm{~m}, 2 \mathrm{H}), 4.20(\mathrm{~m}, 2$ H). ${ }^{13} \mathrm{C}$ NMR $\left(75 \mathrm{MHz}, \mathrm{CDCl}_{3}\right): \delta 22.95,25.48,34.39$ $\left(\mathrm{CH}_{2}\right), 39.31,41.69\left(\mathrm{CH}_{2}-\mathrm{S}\right), 66.32\left(\mathrm{CH}_{2}-\mathrm{O}\right), 76.05(\mathrm{~S}-$ C-S), 112.32 (O-C-O). IR (film): 1430, 1270, 1220, 1170, $1150,1090,1030,960 \mathrm{~cm}^{-1}$.

Cyclohexanespiro-2'-( $1^{\prime}, 3^{\prime}$-dithiolan $)$-2-one (21). Hydrolysis of $\mathbf{2 0}$ as described for $\mathbf{6}$ gave quantitatively the ketone $\mathbf{2 1}$ m.p. $55-56^{\circ} \mathrm{C}$ (lit. ${ }^{17} \mathrm{~m}$.p. $55-57^{\circ} \mathrm{C}$ ). IR (film): $1710 \mathrm{~cm}^{-1}$. The ${ }^{1} \mathrm{H}$ NMR spectrum was the same as that reported. ${ }^{13}$

2,5,7,10-Tetrathia/4.4.4/propellane (22). The compound was obtained from 16 and 1,2-ethanedithiol in $78 \%$ yield as colourless crystals, m.p. $146-148^{\circ} \mathrm{C}$, from methylene chloride. The compound exhibited temperature-variable NMR spectra. ${ }^{1} \mathrm{H}$ NMR $\left(300 \mathrm{MHz}, \mathrm{CDCl}_{3}\right): \delta 1.61(\mathrm{~s}, 4 \mathrm{H}), 2.27$ $(\mathrm{s}, 4 \mathrm{H}), 3.25$ (s, $4 \mathrm{H}), 3.44(\mathrm{~s}, 4 \mathrm{H}) .{ }^{13} \mathrm{C} \mathrm{NMR}(75 \mathrm{MHz}$, $\left.\mathrm{CDCl}_{3}\right)$ : $\delta 24.73\left(\mathrm{CH}_{2}\right), 40.32\left(\mathrm{CH}_{2}-\mathrm{S}\right), 44.99\left(\mathrm{CH}_{2}\right), 81.46$ (C). IR (film): 1790, 1630, 1420, $1090 \mathrm{~cm}^{-1}$.

11,11-Dibromo-2,5-dioxabicyclo[4.4.1]propellane (23a). To a vigorously stirred ice-cooled solution of dihydrodioxin 13a $(0.50 \mathrm{~g}, 3.6 \mathrm{mmol})$, bromoform $(1.82 \mathrm{~g}, 7.2 \mathrm{mmol})$, ethanol $(0.5 \mathrm{ml})$, and triethylbenzylammonium chloride (TEBA, $100 \mathrm{mg}$ ) in dichloromethane $(30 \mathrm{ml})$ was added dropwise a $50 \%$ aq. $\mathrm{NaOH}$ solution $(3.5 \mathrm{ml})$. The reaction mixture was left to stir for two days at room temperature. The organic phase was separated, and the aq. phase extracted with methylene chloride. The combined methylene chloride solution was washed with water and dried $\left(\mathrm{MgSO}_{4}\right)$. Evaporation of the solvent and recrystallisation of the residue from methanol gave the propellane 23a $(0.92$ g, $82 \%$ ), m.p. $72-73^{\circ} \mathrm{C}$. ${ }^{1} \mathrm{H}$ NMR $\left(300 \mathrm{MHz}, \mathrm{CDCl}_{3}\right): \delta$ $1.53(\mathrm{~m}, 4 \mathrm{H}), 2.13(\mathrm{~m}, 4 \mathrm{H}), 3.67(\mathrm{~m}, 2 \mathrm{H}), 3.95(\mathrm{~m}, 2 \mathrm{H})$. ${ }^{13} \mathrm{C}$ NMR $\left(75 \mathrm{MHz}, \mathrm{CDCl}_{3}\right): \delta 20.80,28.02\left(\mathrm{CH}_{2}\right), 46.84$ (C-Br), 59.14 (C), $61.42\left(\mathrm{CH}_{2}-\mathrm{O}\right)$. IR (film): 2920, 1440, $1425,1115,1065 \mathrm{~cm}^{-1}$. GC/MS (C): $m / z 315,313,\left(M^{+}+1\right)$, 233, $231(100)$.

13,13-Dibromo-9,12-dioxa/6.4.1]propellane (23b). Following the procedure described for the preparation of $23 \mathbf{a}$, the reaction of $13 \mathrm{~b}(1.00 \mathrm{~g}, 6.0 \mathrm{mmol})$, bromoform $(3.10 \mathrm{~g}$, $12.0 \mathrm{mmol})$, ethanol $(1 \mathrm{ml}), 50 \%$ aq. $\mathrm{NaOH}(4.5 \mathrm{ml})$ and TEBA (200 mg) in $\mathrm{CH}_{2} \mathrm{Cl}_{2}(30 \mathrm{ml})$ gave the propellane 23b (1.73 g, 85\%), m.p. $67-68{ }^{\circ} \mathrm{C}$, from methanol. ${ }^{1} \mathrm{H}$ NMR $\left(300 \mathrm{MHz}, \mathrm{CDCl}_{3}\right): \delta 1.45-1.85(\mathrm{~m}, 9 \mathrm{H}), 2.18(\mathrm{~m}, 3 \mathrm{H})$, $3.91(\mathrm{~m}, 2 \mathrm{H}), 4.18(\mathrm{~m}, 2 \mathrm{H}) .{ }^{13} \mathrm{C}$ NMR $\left(75 \mathrm{MHz}, \mathrm{CDCl}_{3}\right)$ : d $24.39,26.06,32.73\left(\mathrm{CH}_{2}\right), 46.92(\mathrm{C}-\mathrm{Br}), 62.72(\mathrm{C}), 62.78$ ( $\left.\mathrm{CH}_{2}-\mathrm{O}\right)$. IR (film): $2900,1440,1160,1115,1050 \mathrm{~cm}^{-1}$.

13,13-Dichloro-9,12-dioxa/6.4.1]propellane (24). Following the procedure described for the preparation of 23a the reaction of $13 \mathrm{~b}(0.50 \mathrm{~g}, 3.0 \mathrm{mmol})$, chloroform $(0.54 \mathrm{~g}, 4.5$ $\mathrm{mmol}), 50 \%$ aq. $\mathrm{NaOH}(3.0 \mathrm{ml})$ and TEBA $(100 \mathrm{mg})$ in dichloromethane $(30 \mathrm{ml})$ gave the propellane $24(0.62 \mathrm{~g}$, $86 \%$ ), m.p. $52-54{ }^{\circ} \mathrm{C}$, from methanol. ' $\mathrm{H}$ NMR $(300 \mathrm{MHz}$, $\left.\mathrm{CDCl}_{3}\right): \delta 1.48-1.76(\mathrm{~m}, 10 \mathrm{H}), 2.18(\mathrm{~m}, 2 \mathrm{H}), 3.87(\mathrm{~m}, 2$ $\mathrm{H}), 4.08(\mathrm{~m}, 2 \mathrm{H}) .{ }^{13} \mathrm{C}$ NMR $\left(75 \mathrm{MHz}, \mathrm{CDCl}_{3}\right): \delta 24.26$, 26.10, $30.32\left(\mathrm{CH}_{2}\right), 62.72(\mathrm{C}), 62.79\left(\mathrm{CH}_{2}-\mathrm{O}\right), 68.03(\mathrm{C}-$ Cl).

9,12,13-Trioxa-14,14-diphenyl[6.4.2]propellane (25). A solution of $13 \mathrm{a}(0.70 \mathrm{~g}, 4.2 \mathrm{mmol})$ and benzophenone $(0.76 \mathrm{~g}$, $4.2 \mathrm{mmol})$ in benzene $(80 \mathrm{ml})$ was deoxygenated with nitrogen and irradiated with a 250 Watt medium pressure mercury lamp for $80 \mathrm{~h}$. The reaction did not go to completion. Separation of unchanged starting material by flash chromatography afforded the propellane $25(0.60 \mathrm{~g}, 42 \%)$. Based on recovered starting material the yield was $87 \%$. 'H NMR (300 $\left.\mathrm{MHz}, \mathrm{CDCl}_{3}\right): \delta 1.15(\mathrm{~m}, 1 \mathrm{H}), 1.25(\mathrm{~m}, 5 \mathrm{H}), 1.68$ $(\mathrm{m}, 4 \mathrm{H}), 2.08(\mathrm{~m}, 2 \mathrm{H}), 3.52(\mathrm{~m}, 2 \mathrm{H}), 3.95(\mathrm{~m}, 1 \mathrm{H}), 4.07$ $(\mathrm{m}, 1 \mathrm{H}), 7.17(\mathrm{~m}, 2 \mathrm{H}), 7.27(\mathrm{~m}, 4 \mathrm{H}), 7.54(\mathrm{~m}, 4 \mathrm{H}) .{ }^{13} \mathrm{C}$ NMR $\left(75 \mathrm{MHz}, \mathrm{CDCl}_{3}\right): \delta 23.69,24.71,25.20,25.95$, $33.75,37.30\left(\mathrm{CH}_{2}\right), 58.91,61.55\left(\mathrm{CH}_{2}-\mathrm{O}\right), 81.54,87.86$ (C-O), 105.43 (O-C-O), 125.71, 125.95, 126.21, 126.41, 127.65, $127.77(\mathrm{CH}), 143.48,144.51$ (C). IR (film): 1440, $1140,1115,950,935 \mathrm{~cm}^{-1}$.

\section{References}

1. Fjeldskaar, I. R., Rongved, P. and Skattebøl, L. Acta Chem. Scand., Ser. B 41 (1987) 477.

2. Fjeldskaar, I. R., Grace, D., Rømming, C. and Skattebøl, L. Acta Chem. Scand. Ser., B 42 (1988) 280.

3. Calo, V. and Lopez, L. Synthesis (1984) 774; Lopez, L., Calo, V. and Stasi, F. Synthesis (1987) 947.

4. Bacquet, C., Einhorn, J. and Lelandais, D. J. Heterocycl. Chem. 17 (1980) 831.

5. Griggs, C. G. and Field, I. P. J. Chem. Soc., Perkin Trans. 2 (1985) 1299.

6. Nevalainen, V. and Pohjala, E. Finn. Chem. Lett. 13 (1986) 99.

7. Tanimoto, S., Jo, S., Sugimoto, T. and Okano, M. Bull. Chem. Soc. Jpn. 54 (1981) 3237.

8. Parham, W. E., Heberling, J. and Wynberg, H. J. Am. Chem. Soc. 77 (1955) 1169

9. Massingill, J. L., Jr., Reinecke, M. G. and Hodgkins, J. E. J. Org. Chem. 35 (1970) 823.

10. Erez, M. and Fuchs, B. Tetrahedron Lett. (1971) 4931.

11. Fuchs, B., Auerbach, Y. and Sprecher, M. Tetrahedron Lett. (1972) 2267

12. Dale, J. In: Allinger, N. L. and Eliel, E. L., Eds., Topics in Stereochemistry, Wiley, New York 1976, p. 199.

13. Bulman-Page, P. C., Ley, S. V. and Morton, J. A. J. Chem. Soc., Perkin Trans. 1 (1981) 457.

14. Bredikhin, A. A. and Plemenkov, V. V. Zh. Org. Khim. 12 (1976) 1001; Szalontai, G. Acta Chim. Hung. 126 (1989) 281. 
15. Ghosez, L., Montaigne, R., Roussel, A., de Vanlier, H. and Mollet, P. Tetrahedron 27 (1971) 615.

16. Bak, D. A. and Brady, W. T. J. Org. Chem. 44 (1979) 107.

17. Krepski, L. R. and Hassner, A. J. Org. Chem. 43 (1978) 2879.

18. Huisgen, R., Feiler, L. A. and Otto, P. Chem. Ber. 102 (1969) 3405 .

19. Fetizon, M. and Hanna, I. Synthesis (1990) 383.

20. Huisgen, R. and Steiner, G. Tetrahedron Lett. (1973) 3763.

21. Bouchoux, G., Hanna, I., Houriet, R. and Rolli, E. Can. J. Chem. 64 (1986) 1345.

22. Fetizon, A., Goulaouic, P. and Hanna, I. Heterocycles 28 (1989) 521 and references therein.
23. Jørgensen, F. S., Nørskow-Lauritsen, L., Jensen, R. B. and Schroll, G. Tetrahedron 37 (1981) 3671.

24. Kirby, A. J. The Anomeric Effect and Related Stereoelectronic Effects at Oxygen, Springer, Heidelberg 1983, p. 23.

25. Deslongchamps, P. Stereoelectric Effect in Organic Chemistry, Springer, Heidelberg 1983, p. 21

26. Pericas, M. A., Riera, A. and Guilera, J. Tetrahedron 42 (1986) 2717.

27. Anet, F. A. L. and Anet, R. In: Nachod, F. C. and Zuckerman, J. J., Eds., Determination of Organic Structure by Physical Methods, Academic Press, New York 1971, Vol. 3, p. 343.

Received August 27, 1990. 